\title{
THE CURRENT STANDING AND FUTURE PROSPECTS OF ARTS AND CULTURE IN ETHIOPIA
}

\author{
Karan Khurana \\ Hecho por Nosotros \\ Thames, CABA, Argentina, 1484 \\ khurana101karan@gmail.com \\ Matteo Saraceno \\ Arcs Culture Solidali \\ Bâtiment annexe B, Commune de Dschang, West Region, Cameroon, BP-169 \\ matteosaraceno@gmail.com
}

\begin{abstract}
This research article explores the current state of affairs of arts and culture sector in Ethiopia. An in-depth analysis of various dimensions of art and culture highlights where the country is presently lacking in governance and socio-economic progress in the sector.

A qualitative research was carried out to collect primary data. 52 respondents were chosen to be interviewed from Bahir Dar University by the method of quota sampling and the results were analyzed. Secondary data was also analyzed through academic literature from universities in Ethiopia, reports from government and development organizations. Survey results and existing academic literature have guided to single out major hindrances to this sector.

In this research it can be confirmed, that the arts and culture sector needs a major intervention in terms of governance and marketing. This research gives out a very structural strategy, based on cultural governance, cultural economics and strategies of new business development as it pillars to support the prosperity of this sector in Ethiopia.

The existing academic research provides data on different arts and culture and problems which are specific to a particular region of the country. Whereas this article goes a step further in enforcing the ordinance of cultural governance to the responsible government bodies both locally and nationally and simultaneously highlights how economic progress can be achieved through this sector. Cultural governance as a directive has never been implemented in transition economies and this article will serve as a directive for the future. This article shall be very beneficial for further research in this sector and structuring the work of government bodies, stake holders and the people involved in the sector within Ethiopia.
\end{abstract}

Keywords: Arts and Culture, developing economies, Ethiopia, cultural governance, cultural economics, society.

DOI: $10.21303 / 2504-5571.2019 .00946$

\section{Introduction}

\section{1. Culture and Its importance in $21^{\text {st }}$ century}

Culture is a phenomenon, based on economic and social structure of the society. Human lifestyle is infused with culture in different parts of the globe. As humans embark a new stage of life, one carries a legacy of culture and values ahead and with the passing of generations it gives birth to various dimensions equally unique, colorful and one of a kind experiences. Fridah [1] identifies a continuous process of change but in spite of the change, culture continues to give a community a sense of identity, dignity, and continuity, security and binds society together. Humans have taken support of culture for centuries now in binding with one another.

Culture and development are two fascinating sides of a coin. In case of developed economies both of them are balanced due to the strong financial capability and educated human resource but in case of the developing or under developing economies the debate is much more complex. On one side such economies are struggling very hard to eradicate poverty and provide better health and education and on the other hand art and culture is diminishing. What is more thought-provoking is the fact that in transition economies there is still a very strong essence of culture which is yet to be discovered. Such an example is Ethiopia, one of the oldest civilizations in the world. The country is transiting from an agricultural economy to a fast upcoming industrial economy in the Sub-Saharan Africa. Khurana [2] adds that a decade ago Ethiopia looked like a country to be invariably famous for its coffee and culture but today it is being identified as the next hub for sourcing in the Africa chapter. 
Development could be considered as a reaction where globalization is a catalyst. Globalization further on is paced up by technology and travel. In the last decade, technology grew so fast that the world today is being referred as a global village where nothing seems unattainable. Human curiosity was also aided by cheap travel and access to unusual destinations. This all combined made globalization a persisting problem to culture as the citizens from developing countries were very excited for new additions to their lives. Globalization is multidimensional and affects all spheres of economic, cultural, environmental and social-up to relations between states and nations from the five continents (JRC/OECD, 2008) [3]. Nsibambi [4] argues that globalization is not a value-free, innocent, self-determining process. It is an international socio-politico-economic and cultural permeation process, facilitated by policies of governments, private corporations, international agencies and civil society organizations. Further on Jeremy (2004) [5] adds that globalization is a declaration of war upon all other cultures. When we look from a development perspective globalization is essential and beneficial it has been highlighted in literature [6-8] but parallel to this the citizens of developing countries started to go away from local products and culture.

Modern world is moving at the speed of sound and Ethiopia is adapting to catch up to develop in order to be abreast with time. The arts and culture sector received a back seat in this transformation in terms of governance and management as the priorities shifted totally.

\section{2. Ethiopia and its history with culture}

The name "Ethiopia" derives from the Greek ethio, meaning "burned" and pia, meaning "face": the land of burned-faced peoples. The people of Ethiopia are divided into four main groups:

- Semitic (comprising of the Amhara, Tigre, Guraghe and Adere);

- the Kushitic (comprising of the Oromo, Somali, Afar, Agaw and Beja);

- the Omotic (comprising of the Ghimira, Kaffa and Welaita);

- the Nilo-Saharan (comprising of the Anuak, Gumuz and Baria) [9].

The Oromo (35\%), Amhara (30\%), and Tigreans (10\%) account for more than 75 percent of the population. According to [10] Ethiopia's main languages Ge'ez, Amharic and Tigrinya are Semitic, and they developed through the uninterrupted connection with Arabia and the core countries of the Middle East.

Ethiopia is believed to be one of the oldest civilizations on Earth as we still can see monasteries which were built in the $8^{\text {th }}$ century are still functional. Its historical wealth is embodied in the unique monumental rock-hewn churches dating back to the 12th century, chipped out of solid rock- Lalibela and stelae, ancient monuments and buildings and its unique lettering is clearly an exhibit. Religion has a strong influence on cultural practices of the people of Ethiopia. It is followed in every aspect and each dimension in the culture. According to the Ethiopian Central Statistical Agency, the national religious composition is Orthodox (43.5\%), Protestant (18.6\%), Catholic (0.7\%), Muslim (33.9\%), tradition (2.6\%), and others (0.6\%) [11].

Ethiopian church music is said to have had its beginnings in the sixth century with Saint Yared. As music is a visible component in each occasion (birth, marriage, harvest and even death) of the society; special events have their own special types of music and sometimes instruments, associated with them. The Ethiopian artists did quite a fair job in spreading their cultures to the globe as the traditional themes of church paintings revolved around religious subjects, portraits of rulers, or hunting and battle scenes. However new themes such as daily life, church rituals and legend of the Queen of Sheba are also a part of inspirations. Secular painting appeared much later-seventeenth or eighteenth century-and consisted of murals in churches and palaces, or manuscript paintings, of emperors, princes and princesses, as well as the high aristocracy [12].

Clothing and lifestyle products also exhibit a flare of culture in them. White handloom cotton fabric is the basis of women dresses which is worn on all kinds of occasions. According to Dubois [13], Ethiopian jewelry and ornaments can be divided into the following main groups: smith-made jewelry crafted from various precious and semi-precious metals, bead jewelry and decorative beadwork and ornaments from natural materials. Besides the above mentioned dimensions Ethiopia also has an evident history in handicrafts, literature, drama, film, circus groups, languages and media. Colonization of countries in Africa had its effects on culture and today the effects are 
visible through the way societies have shaped. As Ethiopia stands at the advent of industrialization, it becomes very crucial to preserve and manage its culture in this era of economic reform.

\section{3. The role of governmental organizations in arts and culture sector}

The role of government can't be surpassed in the process of establishing the roots of culture in the country. As the culture dates back, so its organization and governance do. To begin with a chronological snapshot, the first cinema hall, called Seytan Bet (House of the Devil), was opened in the year 1923. After Cinema the establishing of Addis Ababa Fine Art School in 1957 began. Coming to music, Yared Music School was built by the Bulgarian government in 1966.

The "National Museum of Ethiopia" was established in 1944, as a part of the National Library and Archive and the second public museum Harar National Museum (HNM) in 1991. The Ethiopian Antiquities Administration was opened in 1953, followed by The Ministry of Culture, Sports and Youth Affairs in the end of 1975. The Authority for Research and Conservation of Cultural Heritage (ARCCH) is responsible for management of cultural establishment such as museums, theater houses, art school, music school and libraries which are located in different parts of the country.

In the history of Ethiopia, the first step of organizing the cultural sector in a modern manner began recently. Presently in Ethiopia's 2011-2017 Growth and Transformation Plan (GTP) [14], protecting and promoting Ethiopian cultural diversity is a critical element of promoting the cultural policy. As the second (2016-2020) GTP starts, Ethiopia, is now investing more in the development of its lively cultural sector. Ethiopia has now incorporated culture as a strategic element for the second GTP and for the first time dedicated an entire chapter for the cultural sector, setting up benchmarked goals for the implementation. The plan has put in place strategic directions for the culture and tourism development sector; such as enabling citizens' benefit from the sector through conserving and developing cultural and historical heritages and expanding cultural and tourism services and products. This move reaffirms Ethiopia's dedication and the importance of the link between culture and development. The second GTP should seriously look into promoting the culture of the various peoples of Ethiopia and developing these in harmony with the modern education system. The Ethiopian government, searching for an opportunity to develop the tourism industry, has created two governing bodies the Tourism Transformation Council and the Ethiopian Tourism Organization to alleviate obstructions and bottlenecks impeding the development of travel \& tourism and develop the country's strategic plans. One of the notable organizations which has aided the preservation and promotion of culture is Selam Ethiopia (1997 [15]), a non-profit, independent organization, based in Stockholm and created by an Ethiopian born Swedish citizen, engaged in the following key thematic areas: cultural diversity and exchange, capacity building and training, networking and information brokerage, and research.

UNESCO in collaboration with the Ministry of Culture and Tourism, Regional Culture \& Tourism Bureaus, Ministry of Education, Ministry of Foreign Affairs, Ministry of Labor \& Social Affairs, Ministry of Trade, Ministry of Women and Children, Ministry of Youth and Sport, Civil Society has laid a few policies at the Multi-stakeholder Consultation Workshop was held on 9 November 2015, in order to present the 2005 Convention and to consider the status of implementation of the Convention in Ethiopia. The focal concept of this convention is "Development of Cultural Industries" taking into account its economic and social impact.

- National Cultural Policy of the Federal Republic of Ethiopia [16] - to enable the cultural assets and heritage of the Ethiopia's nation, nationalities and peoples to play a key role in creating one economic and social polity through their preservation, development and use as inputs in all development sectors

- The development of Cultural Centers [17]: Currently in Ethiopia there are 9 regional states and two city administrations which host a lot of diversity of cultural expressions. The aim of this policy is studying, enriching, promoting and developing cultural values and features of nations, nationalities and peoples of Ethiopia for social, economic and political development.

- Promoting heritage for Ethiopia's Development (PROHEDEV) [18] - established under the National Cultural Policy, adopted by the Ministry of Culture, it aims to increase the long-term 
contribution of heritage and culture to the socio-economic development of Ethiopia by preserving and developing targeted heritage sites and sectors and improving their management.

- Bi-lateral cultural cooperation treaties [19]: Ethiopia has signed bilateral treaties on cultural cooperation with more than 17 countries since it has become a party to the UNESCO convention in 2008. The bilateral treaties are implemented by the Government together with various stakeholders both at federal and regional level.

Millennium Development Goals Fund (MDG-F) did a project (Harnessing Diversity for Sustainable Development and Social Change in Ethiopia (April, 2013) with UNESCO, UNDP in association with the Ministry of Culture and Tourism and Ministry of Finance and Economic Development. Lack of heritage and culture management were highlighted as the problems and it was noted, that the cultural sector was denied due attention from the government and the people who are directly concerned. The qualitative survey, conducted during this research, also pointed out that $26 \%$ of the respondents believed the hindrances for culture to sustain should be dealt properly in different regions of the country.

Below are listed some of the challenges as listed in literature:

- Mocria et al. [20] compiled a report in association with the Swedish International development Cooperation Agency (SIDA). They suggested that all of the country's movable works of arts that are in the hands of the Ethiopian Orthodox Church were not well maintained. They are placed one on top of the other in ill ventilated stores, infested with termites and other insects, or constantly touched and rubbed by unclean hands. The stores have no theft-proof locks and are vulnerable to fire and other natural and man-made calamities. The storekeepers of these valuable works of art are underpaid and so are easily tempted by fortune seeking tourists. As a result, there is now a big outflow of cultural properties from the country through illegal means [20]. Similarly the music and dance sector suffers from the lack of skilled manpower and copyright issues.

- Girma Bulti [21] in his master research pointed out that there are works which do not fit the standards of a museum and nobody knows who brought them. In terms of administration, the "National Museum of Ethiopia" does not establish relationship with the concerned stakeholders such as governmental and non-governmental institutions. The other challenge is that there is no systematic documentation to identify easily the art works.

- Bula Sirika focused on researching on Handicrafts sector in the West Wallaga (Southwest Ethiopia) and found similar challenges, related to governance and management of the sector. According to Sirika [22], the handicraft of this region has got inadequate attention from both the regional governments and non-government agencies, as he marks that institutions are focusing mainly on farming which alone cannot be a guarantee to help a given society to attain reliable development.

- Nigussu Mekonnen Abay [23] in his research on the National Museum Ethiopia (NME) found that stakeholder engagement practice efforts and its service delivery positions are diminishing from one year to another due to many reasons. These are including the scarcity of the necessary budget, human resource, conceptualization, improper organizational structure, the absence of museum legal frameworks etc. Epy study identified the absence of clearly defined stakeholder engagement policy (94.64\%), lack of appropriate museum organizational structure and good governance $(80.36 \%)$, shortage of skilled museum professionals $(76.79 \%)$. In addition to this, lack of commitment from the governing bodies of the "NME" (67.86\%) and the problem of attracting donors and sponsors to the museum (64.29\%) respectively were identified as the major obstacles for the "NME" $\mathrm{s}$ " stakeholder engagement practices.

- The research of Belle Tarsitani on the Museums of Harrar pointed out a very different yet very critical angle which was to identify the visitors. It was found that African museums, like their counterparts around the world, are questioning the social relevance of museums and museology as an academic discipline in the local and global context. They are asking, what is and what should be the role of the museum in the community? [24]. Moreover, visitors to African museums continued to be elite people and the style of exhibitions and captions for displayed objects retained references to the "tribalism" of the material heritage. 
This article aimed at analyzing the current status of arts and culture sector in the country and highlights the obstacles, faced in the past. It further on provided probable solutions in light of cultural governance and cultural economics for a prosperous future of this structuring of the sector.

\title{
2. Research Methodology
}

In order to find out the status and problems of art and culture in Ethiopia both secondary and primary data were analyzed.

The students on a pair with staff members were qualitatively interviewed at Ethiopian institute of textile and fashion technology (EiTEX), Bahir Dar University. EiTEX is the only institute in Ethiopia offering fashion design, textiles and leather engineering courses at undergraduate and post graduate levels, therefore a mix of all regions could be found at one place. A qualitative analysis with open ended questions was performed within the university. The quota sampling method was used to collect data from 52 respondents. This helped to measure the concern and status of awareness amongst the citizens from different regions and to spread the message of importance of preserving and promotion of culture. The reason to choose the research at the university was the presence of young citizens from various parts of the country. However, as the students do not belong to arts and cultural studies directly, secondary data such as academic literature from universities, reports of development associations and government organizations were also analyzed to strengthen the ideas and provide a better base of problems. This analysis provided us a much clear picture on the hindrances, thus making it much more structured to provide solutions for this sector.

\section{Results and discussions}

In the qualitative survey nine open end questions were analyzed and following are the results of the survey.

Question 1. Are arts and culture valued in Ethiopia? If yes, what are the ways through which culture is promoted? (Fig. 1).

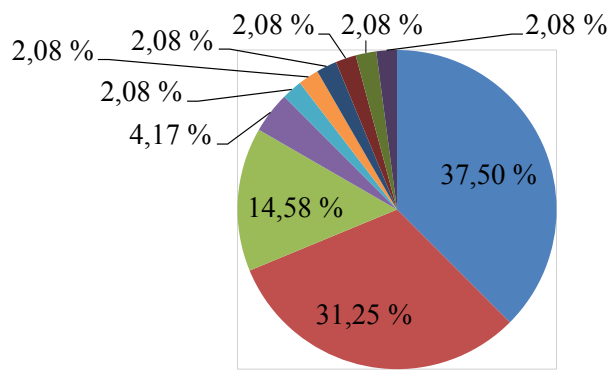

\author{
- More valued \\ - no comment \\ n Part of society/Traditions \\ - Local community \\ - Religion \\ - UNESCO \\ - Other organisations \\ - Art not recognised \\ - Some value \\ - No worth
}

Fig. 1. Value of Arts and Culture. Source: Authors

In Fig. 1 we see that a vast majority of the respondents (68.75\%) believe that arts and culture are valued in the country, but what is simultaneously alarming that $(31.25 \%)$ did not comment on it showing that they were no aware on its value. Further on it is also seen that External (exogenous) factors such as UNESCO and other development organizations influence the promotion of culture and arts by $(4.17 \%)$. It is also very interesting to find that still a large part of the society practices culture and $20.83 \%$ agree to the fact that culture is a part of society/ traditions, religion and local community. A bit disappointing result here is that $6.25 \%$ respondents believe that either forms of art are not valued or have less worth. In short, one person on five related the value of culture to endogenous factors like the local society, communities and religion. 
Question 2. In what forms Culture is visible in Ethiopia? (Fig. 2).
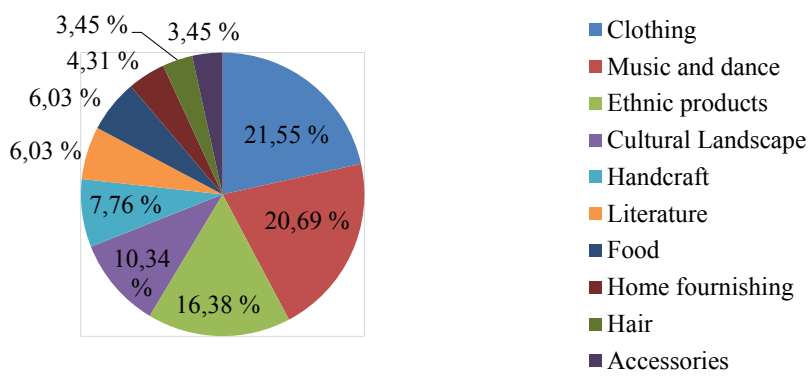

Fig. 2. Forms of Cultural products. Source: Authors

Ethiopians value their culture and it's a part of their daily lives, it can be seen, that traditional clothing $(21.55 \%)$ and music and dance $(20.69 \%)$ are occupying the major percentage of expression of culture, followed by Ethnic products (local made artisan articles).

Question 3. In what forms Art is visible in Ethiopia? (Fig. 3).

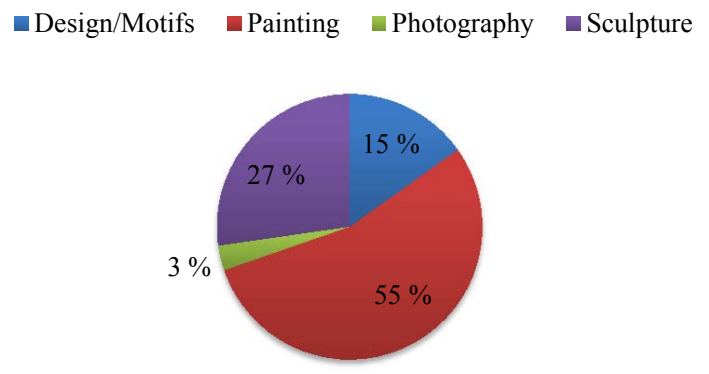

Fig. 3. Art Forms. Source: Authors

We also delved in the issue of arts to find out much more in detail what kind of art forms are found in Ethiopia. In Fig. 3 it's displayed, that the respondents pointed out that majorly visible art forms were paintings (55\%), followed by sculptures (27\%) and design/motifs (15\%).

Question 4. How much local communities value their own local arts and culture? (Fig. 4).
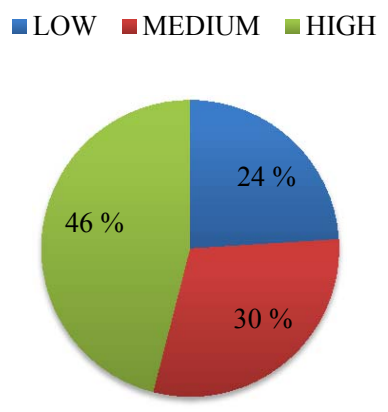

Fig. 4. Local Communities and Culture. Source: Authors

The respondents displayed a lot of confidence in local communities, according to the survey, $46 \%$ believe that the local communities value culture a lot. It can also be added, that the value of the culture towards local artisans and communities is much more as compared to urban population as products they create out of their cultural inheritance also serve as a source of livelihoods. The urban population is $20.4 \%$ of total population (2017) [25]. Ethiopia is a predominantly agricultural country where more 
than $80 \%$ of the population lives in rural areas that is in the early stages of demographic transition. This is particularly an interesting opportunity to find the right place of saving arts and culture.

Question 5. How are local arts and culture supported commercially in Ethiopia? (Fig. 5).
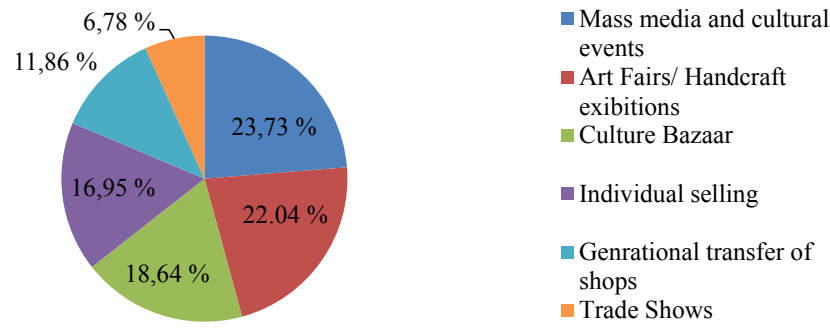

Fig. 5. Local communities and business opportunities. Source: Authors

Fig. 5 above exhibits the promotion and commercial activity of the crafts. It can be seen, that a large percentage depends on mass media and cultural events $(23.73 \%)$ and art exhibitions $(22.04 \%)$, followed by culture bazaar (18.64\%) in Addis Abeba. The struggle of arts and cultural products from local artisans is evident as individual selling approach is a very small portion $28.81 \%$ (individual selling and generational transfer) of the total share. More than $71 \%$ sellers rely on external factors or support from the government or associations.

Question 6. What would happen if there was no support from government or associations? (Fig. 6).
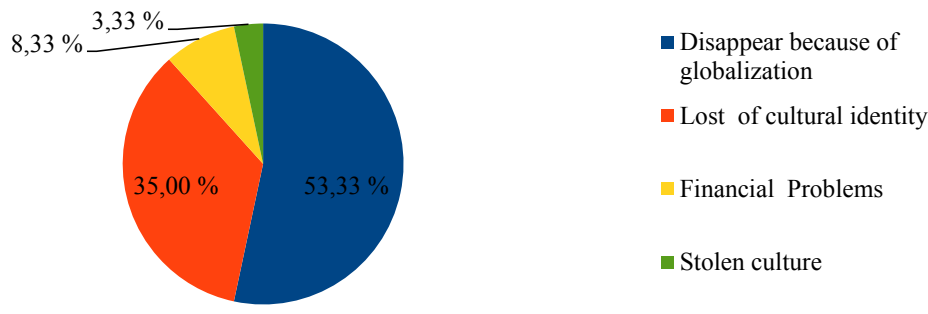

Fig. 6. Effect of no external support. Source: Authors

As is observed in Fig. 7. Majority of the commercial activity is carried out by external support, so we went further in detail to find out what would happen if the support was not provided. Surprisingly $53.33 \%$ believe that the arts and crafts will be lost due to competition as effects of globalization. $35 \%$ also believe that there would be a loss of cultural identity and this is surely identified as a big problem for developing economies. Simultaneously respondents $(8.33 \%)$ believe that financial problems would also arise for the artisans as well as their art needs recognition and commercial viability.

Question 7. Should there be funding? If so, from what resources (Fig. 7).
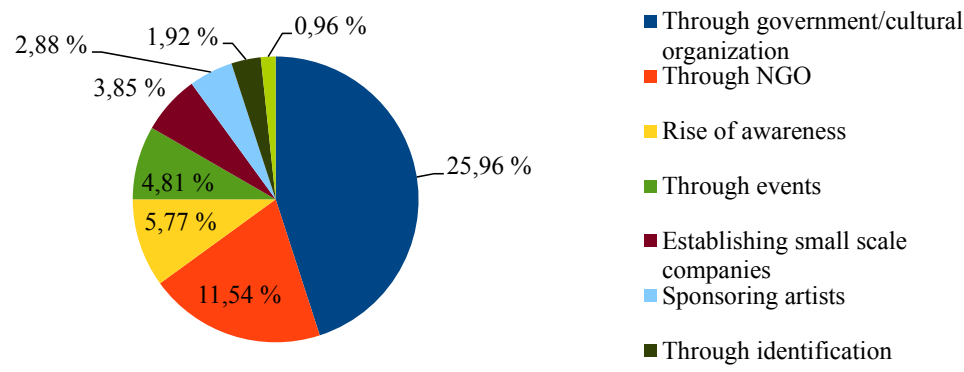

- Through identification

Fig. 7. Sources of Funding. Source: Authors 
Financial issues in arts and culture have always been an issue in developing economies. Majority of the respondents agreed that the arts and culture sector needs funding to grow. But what was surprising is that $42.31 \%$ had no answer to should there be funding or not. According to $25.96 \%$ of the respondents, the government and cultural organization currently provides funding, followed by NGO'S (11.54 \%). Events and awareness (around $10 \%$ ) also play a role in attracting funds for local arts and culture. Particular interesting here is creating arts and culture as small scale industries. Khurana and Ryabchykova [26] suggest in their research that entrepreneurship development is essential to solve the problem of economic development through creating local employment, balanced area development, decentralization of economic power and diversion of profits from rich to the middle class \& poor.

Question 8. Do existing art and cultural organization receiving funding - whether local funding or international? (Fig. 8).

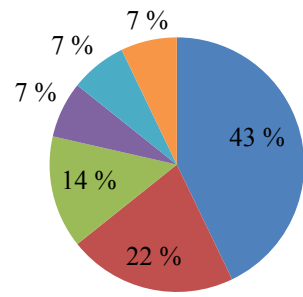

\author{
- UNESCO \\ - Religious Organization \\ - Cultural Dance groups \\ - German government programs \\ - YEGNA Cultural group \\ City Culture Center(Mululealem)
}

Fig. 8. Existing Sources of Funding. Source: Authors

On being asked about the current status of the funding programs the respondents seems to have maximum knowledge about UNESCO (43\%), followed by German government programs (GIZ) (7 \%). Religious organizations also hold a good share (22\%) in funding along with other city culture centers and groups.

Question 9. What are the challenges facing the future of arts and cultural sector in Ethiopia? (Fig. 9).
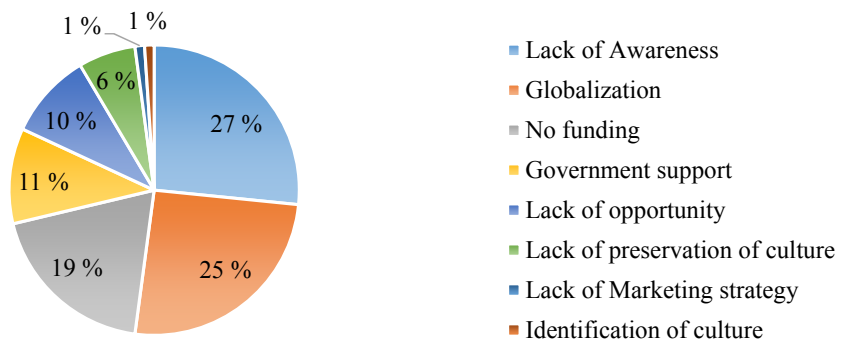

Fig. 9. Challenges facing the future of arts and cultural sector. Source: Authors

Finally we addressed to the respondents the challenges, faced by the art and culture sector. The respondents pointed out that awareness (27\%) about the issues was a huge problem and this was backed by globalization ( $25 \%$ ). It was also found in the interviews, that government support and funding was also a major issue.

\title{
4. Proposed Solutions for growth of the Arts and Culture Sector in Ethiopia
}

In accordance with the survey results we propose certain methodologies for the future conditioning of the arts and culture sector.

\section{1. Culture as catalyzing factor for growth in Developing Economies}

The role of cultural aspects in a country development process is a complex matter to handle, especially regarding the great numbers and variety of the experiences that could be observed in 
the world history. A set of new technologies, even if profitable, could be adopted in a society with success only if it arrives to deal with the peculiarity of the receiving culture. Traditionally unless a society has a certain set of institution and policies [27], they will not experience a long-term economic grow and development. A culture is the result of centuries of changes due to human and natural fate [28] that generates a local Identity: a sort "tool kit" [29] of customs and tradition that characterizes the internal dynamics of each group. In accordance with academic literature [30-32] there are some key aspects of "tool kits" that have been found to be common to many successful cultures, and all of them deal with the capacity of a society to create a trusted structure of regulation of the individuals' efforts. Their strength is in the good governance, in a set of production technologies and durables, schemes of distribution of wealth, "adopting a set of values that are compatible with humanity's moral development" [33]. That set of values can be dominant or minor in a particular historical moment of a society with a direct influence on the resistance to change.

An economic development process, inducing a change in social behavior, produces different reactions to innovation in the different groups, according to their specific identity. A culture determines the decision of consumption, investment and savings of nations and individuals, based on their subjective utility function. When a process of development in a given area is undertaken, it should be considered, that culture is strictly connected to identity, and the probability of success is higher if a sense of ownership is born inside the society. An investment or program has to be centered on the philosophy that hinges on local culture. It's necessary to adopt a bottom-up approach, based on communities' participation through the concentration of decisions and definition of roles and responsibilities. In this way the social conflict could be prevented and the change is rooted as much as possible in the local anthropological context.

In a strongly and interconnected world the creativity unavoidably ends up flattering in the dominant globalized model, the creation of an initiative that takes into account the peculiarities of cultural identity can bring new catalyzing resources to global innovation, triggering a virtuous circle of growth. The ideas, the imagination, are the engine of creativity in a multi-ethnic society that can take advantage from the cultural cooperation and the creation of social capital. Public intervention in culture and education should stress on the infrastructure investments in the improvement of the market image of the territory. A crucial move would be less onerous bureaucratic procedures to encourage internal and international investment. This will generate a self-induced labor demand for the tourism and the "culture industry" that have always been a trigger for innovation and growth for the economy.

The culture growth induces a change in the composition of the demand, influences the functions of utility of consumption and investment [26], including new value towards new and probably higher equilibrium of GDP. A development process involves a change in the dominant culture, there's an influences in the behavior of the decision makers: "A number of empirical studies confirm that culture is an important mechanism that helps explain why historical shocks can have persistent impacts" [34]. Empirical results [35] pointed out that in the nations, where there are longterm growth-promoting institutions, the favorable culture to encourage the development is created.

When we deal with developing economies, in situation of poverty, the level of education gives a thin understanding of what is the real potentiality of the available resources. The population is involved in the "culture of poverty" [36, 37], where there are different cognitive evaluations of good and bad and the consequent resources of mobilization that can cause the stagnation of underdevelopment. Culture is a dynamic process [38], in which people define, who they are, what they desire and how they seek to realize their goals. Researchers [39] affirms the importance of the cultural understanding for the development of partnership with international constituents, the regions that have a traditional ability to cooperate, have advantage, especially when we try to introduce innovations.

According to Tabellini [40], culture is the principal component of four values, linked with the economic performance: belief in the importance of individual effort, trust, generalized morality and law obedience. When the concept of autonomy, egalitarianism, rule of law, less corruption, and democratic accountability is incorporated in the culture from a long time in the past, there is a positive and statistically significant effect on today's social values and exploitation of the endogenous factors of growth. Each culture has some positive and negative aspects, the positive ones cannot be translated in development if are not met some necessary conditions like policies, effective institu- 
tions, favorable world economic situations, and political stability. These conditions arrive, when the cultural approach relate to development policy options and institutional choice to certain cultural antecedents that explain the self-regulation of behaviors of the population [41].

\section{2. Cultural Governance and its relevance for Ethiopia}

Various authors have examined culture governance, according to different perspectives. Moon [42] suggests Cultural governance, defined as government's direct or indirect involvement in the promotion and administration of programs of cultural organizations (including museums), existing in specific geographic boundaries with unique financial and administrative arrangements, whereas Schmitt [43] deals with the concept of cultural governance from the perspective of sociologically-informed cultural studies.

Through a detailed study of academic literature and analysis of the surveys, it can be clearly understood, that the country lacks culture management. In order to build a structured strategy for the future of arts and culture in Ethiopia the author considers the five principles of good governance for cultural organizations by [44]. In light of these principles Khurana [9] grounded a guideline that could be formed in order to amend the current state of affairs in Ethiopia.

- The role and powers of the governance bodies should serve the objectives and the mission of the organization.

A common problem in under-developing economies is that sub-organizations/support offices have often invested time in playing the blame game or if not this they got stuck in the bureaucratic procedures. The result was not favorable either. Directives from the central authorities are never enough to the regional procedures, when it comes to promotional activities and maintenance of the heritage sites. The regional offices of tourist destination such as Lalibela, Axum or Harrar should have a set of designated activities, so that they can act quickly to their local problems. In the light of this principle if there would be a clear guideline form the Ministry of Culture and Tourism to act locally it shall be very beneficial on each point of action.

- The governance bodies should be accountable to each other: the principle of checks and balances plays a central role in this regard.

Right division of responsibilities and timely action shall be a crucial factor in the future of culture and art. But it should not be missed here that in case of routine issues the regional and head government bodies should be accountable to each other. The areas, where major attention is needed to be paid, are distribution of funds and troubleshooting problems which require immediate attention. A continuous system of checks and reporting in different regions shall develop a good data base of issues that the cultural communities are facing and one region issues shall serve as a solution to another and vice-versa. Researchers have noted that the state of artifacts and maintenance of cultural artifacts in museums is not very well. Ethiopia has established museums in various parts of the country but accountability of works of art is a critical issue which can't be maintained by the establishing authorities, but is a direct concern of the regional offices. Moreover, the ministry should keep a check on where the funds have been equally distributed, invested and are they being utilized in the upgrading various art and culture centers.

- Governance bodies should operate in a transparent manner and keep each other suffciently informed about their operations and decisions.

To start with, Amharic language is a barrier at the offices for foreigners to communicate or find information. The reason for such a situation is that the higher government bodies have ordered not to share any information which is not in interest of the country and is totally justified. Such kind of transparency in daily operations and decisions increases the efficiency of the system from within and makes them more responsive to a number of issues.

- The composition of the governance bodies for arts and culture sector.

The composition of government bodies has to be very precise in order to meet the objectives which are identified by the country. The personnel, identified for such roles in the governance board and the regional office, need to have the right interest in preserving country's culture. Schramme et.al [44] suggest that in addition to the desired profiles and competences, a differentiated composition has to do with such aspects as gender ratio, ethnic diversity and generational distribution. 
Roles of each profile should be clearly defined in order to not to miss on critical issues. Issues, regarding ethical information sharing to the world, hold a lot on importance in this case and should be carefully dealt. It is understood, that developing nations might have issues in sharing of information in streams of culture as sometimes it interferes at the political front of the country.

UNESCO and other voluntary organization have helped Ethiopia in the past by providing volunteers, working in areas of culture and arts. Inputs from volunteers and researchers could help in implementing good measures for this sector and hence strengthening of the working force.

- The value and contribution of stakeholders (internal and external).

The role of stakeholders in museums and other governmental organizations is very crucial in maintaining the existence of arts and culture. Stakeholders are both internal and external in nature. In the case of Ethiopia the government has sources of funding from countries like Japan (Japan International Cooperation Agency -JICA), Germany (German Society for International Cooperation-GIZ) and Korea (Korea International Cooperation Agency-KIOCA) to name a few. The government bodies should work with these external partners to leverage on knowledge sharing and better utilization to upgrade the status of culture and arts in the country. This co-operation could be regional in nature and can spread to various regions, where the problems have been identified.

In the light of the above five principles above it can be understood, that the concept of cultural governance could help the country`s heritage in a big way. However, the task still remains to the government body as how to implement these principles. In smaller towns the awareness of culture is very limited. As described earlier in the case of local artisans, who are making a livelihood through cultural adaptations, the local public seems to show no interest until it attracts some monetary benefits in forms of tourism. The education on the importance of culture is almost absent as the exiting culture and tourism offices in small cities make no efforts to pass this message to the youth. It is also seen, that the local government bodies heavily depend on the center for aid and thus often missing the main goal. The data analyzed is through the students, who are studying in the universities or various NGO's/development corporations, but as the larger part of the country still in the rural it will be very crucial to educate the citizens to preserve and promote the rich culture.

\section{3. New-age Marketing methodologies}

In managing the arts and culture sector the next crucial step here is marketing, which is presently absent in this sphere. The business modeling for arts and culture should essentially involve more exposure to local artisans and not just heritage sites. A multi-dimensional business model shall serve a great leap; it shall not only let the rural escape poverty, but serve as an automatic promotion of culture from the various parts of the country to the center and then internationally. A good measure is to organize regional and national fairs in the country in order to speed up promotion. In the last decade marketing has evolved majorly across industries and has given way to new methodologies of promotion and launch of new products. The ever increasing use of social media in our generation has bought many contemporary ideas into light [45]. Selling art and other culturally oriented products online through an image based platform such as YouTube and Instagram have become very popular in promotion around the world. Social media is practically free to propagate the messages around the world and such an example is The Rijksmuseum in Amsterdam which digitalized and released 125,000 works in its collection for free use. Such tasks shall need a high degree of combined involvement and control from the cultural organizations and NGO's/development corporations to provide a push to the arts. In a broad analysis it is evident, that people do value the arts and culture both locally and nationally, but do not have proper channels to keep up with the rest of the world in terms of promotion and hence often miss out. Through the implementation of the principle and policies of cultural governance it could be much easy to not only promote the culture but also bring empowerment to the citizens.

\section{Conclusions and Further scope of Research}

1. Through this article the authors have touched various facets of art and culture in a developing economy. In this article the authors not only highlight the problems of the sector but also find solutions in lines of cultural economics, governance and marketing. It cannot be said, that the 
government did not take charge of the progress and preservation of arts and culture, but currently they need to essentially shape their governance policies for a better future and economic development through this sector.

2. The fact that the country was never colonized has helped the art and culture to be intact, but in terms of policies it's quite a slack due to old ideologies [9].

3. From the grass roots level, today a most common challenge is saving and preserving the artisan, who is the bearer of culture and arts as in urban jungle.

4. This article has grounded the various facets of Ethiopian culture and theory of cultural governance in accordance to Ethiopia and simultaneously opens a vast scope of research in implementation of these principles.

5. Presently there is a huge gap in marketing and new business policies in this sector and it is open to the academia and cultural organizations for further research. The process of restructuration and implementation is time consuming, but provides various new areas of research opportunities in this sector.

\section{Compliance with Ethical Standards}

The authors have complied with the Ethical Standards of the journal.

\section{Acknowledgement}

This research did not receive any specific grant from funding agencies in the public, commercial, or not-for-profit sectors

\section{Conflict of Interest}

The authors declare that they have no conflict of interest.

\section{References}

[1] Fridah, M. (1998). The effects of globalization on Africa culture in the eyes of an African woman. ECHOES. World Council of Churches WCC. Available at: https://www.oikoumene.org/en/resources/documents/wcc-programmes/public-witness-addressing-power-affirming-peace/poverty-wealth-and-ecology/neoliberal-paradigm/the-effects-of-globalization-on-culture-in-africa-in-the-eyes-of-an-african-woman

[2] Khurana, K. (2018). An overview of textile and apparel business advances in Ethiopia. Research Journal of Textile and Apparel, 22 (3), 212-223. doi: http://doi.org/10.1108/rjta-01-2018-0003

[3] JRC/OECD (2008). Handbook on Constructing Composite Indicators. Methodology and User Guide. Paris: OECD Publishing. Available at: https://www.oecd.org/sdd/42495745.pdf

[4] Nsibambi, A. (2001). The effects of globalization on the state in Africa: Harnessing the benefits and minimizing the costs. Paper presented at UN General Assembly, second committee: Panel discussion on globalization and the state. Available at: http:// unpan1.un.org/intradoc/groups/public/documents/un/unpan001978.pdf

[5] Seabrook, J. (2004). Localizing Cultures. Available at: https://www.globalpolicy.org/component/content/article/162/27633.html

[6] Manolică, A., Roman, T. (2012). Globalization-advantages and disadvantages from the perspective of the manufacturer. CES Working Papers, 4 (4), 747-757.

[7] Oyelaran-Oyeyinka, B. (2004). How can Africa benefit from globalization? ATPS Special paper series, 17. Available at: https:// atpsnet.org/wp-content/uploads/2017/05/special_paper_series_17.pdf

[8] Wang, W., Wang, R., Kossi, A., Stephanie, N., Josphert, N. K., Judith, M. P. (2012). The impact of globalization on African countries economic development. African Journal of Business Management, 6 (44), 11057-11076. doi: http://doi.org/10.5897/ajbm12.828

[9] Khurana, K.; King, I., Schramme, A. (Eds.) (2019). Ethiopia. Cultural Governance in a Global Context. Palgrave Studies in Business, Arts and Humanities. Cham: Palgrave Macmillan, 21-50. doi: http://doi.org/10.1007/978-3-319-98860-3_2

[10] Erlikh, H. (2013). Islam, Chirstianity, Judaism and Ethiopia: The Messages of Religions. Nehemia Levtzion Center for Islamic Studies, Institute of Asian and African Studies, Hebrew University of Jerusalem. Available at: https://openscholar.huji.ac.il/ sites/default/files/levtzion/files/nvskh_ktvb_2009.pdf

[11] Wayback Machine. Available at: https://web.archive.org/web/20120214221803/http://www.csa.gov.et/pdf/Cen2007_firstdraft.pdf

[12] Eshete, A. (1982). The cultural situation in socialist Ethiopia. Unesco, 56.

[13] Dubois, J. (2008). Roots and Flowerings of Ethiopia's Traditional Crafts. Unesco, 43.

[14] Ethiopia's Growth and Transformation Plan -nearing the half-way mark. Available at: http://aigaforum.com/articles/ethgtp-plan-half-way.pdf

[15] Selam Ethiopia. Available at: https://en.unesco.org/creativity/policy-monitoring-platform/selam-ethiopia 
[16] National Cultural Policy of the Federal Republic of Ethiopia. Available at: https://en.unesco.org/creativity/policy-monitoringplatform/national-cultural-policy-federal

[17] The development of Cultural Centers. Available at: https://en.unesco.org/creativity/policy-monitoring-platform/developmentcultural-centers

[18] Promoting Heritage For Ethiopia's Development (PROHEDEV). Available at: https://en.unesco.org/creativity/policymonitoring-platform/promoting-heritage-ethiopias

[19] Bi-lateral cultural cooperation treaties. Available at: https://en.unesco.org/creativity/policy-monitoring-platform/bi-lateralcultural-cooperation

[20] Mocria, E., Messele, M., Hiwot, A. G. (2003). Survey of culture and media: Ethiopia. Stockholm.

[21] Bulti, G. (2016). The state of painting collections at the "national museum of Ethiopia". 2016. Available at: http://etd.aau.edu.et/ handle/123456789/443

[22] Sirika, B. (2009). Socio-economic Status of Handicraft Women Among Macca Oromo of West Wallaga, Southwest Ethiopia. Ethiopian Journal of Education and Sciences, 4 (1). doi: http://doi.org/10.4314/ejesc.v4i1.42987

[23] Mekonnen, N. (2016). Stakeholder engagement at the "National Museum Ethiopia".

[24] Tarsitani, B. A. (2009). Merging Past and Present in the Museums of Harar, Ethiopia. Available at: https://www.everythingharar.com/images/pdf/publication/Mergingpast \%20and \%20present.pdf

[25] The world factbook archive. Available at: https://www.cia.gov/library/publications/the-world-factbook/geos/et.html

[26] Karan, K., Kateryna, R. (2018). Sustainable Business Strategies for Local Fashion Communities (small and medium scale enterprises) in Ethiopia and Ukraine. Fashion \& Textile Research Journal, 20 (1), 22-33. doi: http://doi.org/10.5805/sfti.2018.20.1.22

[27] Private Propriety, freedom of contract, limited scope regulation, monetary restraint, fiscal responsibility and open trade.

[28] Hardin, G., Diamond, J. (1997). Guns, Germs, and Steel: The Fates of Human Societies. Population and Development Review, 23 (4), 889. doi: http://doi.org/10.2307/2137390

[29] Swidler, A. (1986). Culture in Action: Symbols and Strategies. American Sociological Review, 51 (2), 273-286. doi: http:// doi.org/10.2307/2095521

[30] Clark, G. (2008). A farewell to alms: a brief economic history of the world. Princeton University Press, 432.

[31] Hezel, F. X. (2009). The Role of Culture in Economic Development. Available at: http://www.micsem.org/pubs/counselor/ frames/culture_economic_developmentfr.htm

[32] Landes, D. S. (1998). The wealth and poverty of nations: Why are some so rich and others so poor. Available at: https://tsu. ge/data/file_db/faculty_humanities/Landes \%20- \%20The \%20Wealth \%20and \%20the \%20Poverty \%20of \%20Nations.pdf

[33] Lopez-Claros, A., Perotti, V. (2014). Does culture matter for development? Policy Research Working Paper Series 7092. The World Bank, 32. Available at: http://documents.worldbank.org/curated/en/104741468325132310/Does-culture-matter-for-development

[34] Nunn, N. (2012). Culture and the Historical Process. Economic History of Developing Regions, 27 (1), S108-S126. doi: http:// doi.org/10.1080/20780389.2012.664864

[35] Acemoglu, D., Johnson, S., Robinson, J. A. (2001). The Colonial Origins of Comparative Development: An Empirical Investigation. American Economic Review, 91 (5), 1369-1401. doi: http://doi.org/10.1257/aer.91.5.1369

[36] Borjas, G. J. (2001). Does Immigration Grease the Wheels of the Labor Market? Brookings Papers on Economic Activity, 2001 (1), 69-133. doi: http://doi.org/10.1353/eca.2001.0011

[37] Ellwood, D. T. (1988). Poor support: Poverty in the American family. Basic Books. Available at: https://www.worldcat.org/title/ poor-support-poverty-in-the-american-family/oclc/17507301

[38] Fellner, A. (2008). "Role of culture in economic development: Case study of China and Latin America" Graduate Theses and Dissertations. Available at: http://scholarcommons.usf.edu/etd/236

[39] Baldauf, A., Cravens, D. W., Wagner, U. (2000). Examining determinants of export performance in small open economies. Journal of World Business, 35 (1), 61-79. doi: http://doi.org/10.1016/s1090-9516(99)00034-6

[40] Tabellini, G. (2010). Culture and Institutions: Economic Development in the Regions of Europe. Journal of the European Economic Association, 8 (4), 677-716. doi: http://doi.org/10.1111/j.1542-4774.2010.tb00537.x

[41] Chu, G. C. (1993). The great wall in ruins: Communication and cultural change in China. SUNY Press, 366.

[42] Moon, M. J. (2001). Cultural governance: A comparative study of three cultural districts. Administration \& Society, 33 (4), 432-454. doi: http://doi.org/10.1177/0095399701334003

[43] Schmitt, T. M. (2011). Cultural governance as a conceptual framework. Available at: https://www.researchgate.net/publication/274256653_Cultural_Governance_as_a_conceptual_framework

[44] Schramme, A., Schrauwen, J., Rommes, C. (Eds.) (2012). Goed bestuur voor cultuur: over'corporate governance'in de cultuursector. Available at: http://www.kunstenenerfgoed.be/sites/default/files/uploads/161006_leidraad \%20cultural \%20governance.pdf

[45] Khurana, K. (2017). Fashion and location: a contemporary ideology to explore social media as a tool for teaching and learning in design. E-methodology, 125-134. 